\title{
Comparative Research on Family Moral Education between China and America
}

\author{
Liu LIU ${ }^{1, a,{ }^{\star}}$, Tong-Bo ZHANG ${ }^{2, b}$ \\ ${ }^{1}$ School of Marxism, Tianjin University of Technology, Tianjin, China \\ ${ }^{2}$ School of Marxism, Tianjin University of Technology, Tianjin, China \\ a1031975536@qq.com, b459924348@qq.com \\ ${ }^{*}$ Corresponding author
}

Keywords: Family Education; Moral Education; Comparative Research

\begin{abstract}
In recent years, with Comrade Xi Jinping as the core of the Party's Central Committee, the topic of family education has been mentioned by comrade Xi Jinping in many speeches. As one of the important parts of education, family education plays a vital role in ideological work. Moral education is the fundamental work of family ideological and political education, so family moral education is especially important. This paper mainly analyzes current situation of education in Chinese family morality and education in American family, expound the influence and problem of family moral education. In the end, the paper summarizes the reference value of American family morality education to Chinese family morality education. Based on the Chinese excellent tradition culture, Chinese family morality education can select the essence and abandon the dross.
\end{abstract}

\section{Introduction}

Family education provides social morality education with education basis, which is the primary environment for the growth of teenagers and the core of building a socialist modern civilized family. Whether in the East or West, family morality education has its own education background and education characteristics. Therefore, teenagers in the East and West teenagers, being affected by education pattern and education content, have different life habits, behaviors and values.

\section{The Current Education of Chinese Family Morality Education}

"Exam-oriented education" is an important long-term problem in China's education system for long time, but it cannot deny the relative fairness and scientific nature of exam-oriented education. Actually, "exam-oriented education" is derived from the traditional imperial examination system which can date back to ancient China and belongs to a special education model in China. Since 1993, although the government has issued various policies to promote the quality of education, the "exam-oriented education" mode still permeates all aspects of education activities and affects the reform process of education in China. "exam-oriented education" system, an education mode that focuses on intellectual development, neglects moral development, the examination result is the only criterion to evaluate a student's excellence. Although education has its relative fairness and impartiality, and can change the future for many students living in poverty and substandard life, we must objectively see that "exam-oriented education" lacks of development in students' personality and cultivation in creative ability. The goal of the Exam-oriented education is just to memorize knowledge, to 
pass the examination, to get a high mark. In teaching activities, the main education method is the infusing knowledge. Family education is closely related to school education and social education, so "exam-oriented education" directly influence family education environment. As the core parts of school education environment and social education environment. The education form determines the concept, goal, content and method of family education. Under the education system with "exam-oriented education" as the core, the concept of family education presents a utilitarianism development trend. Parents adopt various methods to improve their children's academic performance, evaluate their children's quality with test scores, and measure the teaching level of school teachers. Even though children usually take art courses, such as Musical Instruments, painting, sports, their parents also hold the psychology of extra points in exams, or in order to meet the psychological comparison between parents.

In addition, Chinese parents often advocate the slogan "don't let your children lose at the starting line", which also affects parents' attitude towards learning with a utilitarian attitude. With the improvement and development of various aspects in China in the past two years, this utilitarian mentality has slowed down. Parents are willing to allow their children to participate in extracurricular practice and respect their children's hobbies, but they still insist on "exam-oriented courses". Parents work with the school's "exam-oriented education" to set learning goals for their children. At the same time, parents and schools jointly form a kind of "high-pressure" environment. As a result, they ignore the cultivation of teenagers' moral education and force their children to improve their scores to satisfy their parents' expectations.

The institutional environment of "exam-oriented education" leads to the characteristics of family education content simplification. Parents' praise for examination results inevitably leads to neglect the exercise of children's practical ability, the cultivation of innovative thinking and the formation of moral quality. The only task for a child is to study hard and not worry about anything else. Learning is first, and everything else is secondary. This kind of arranged family education kills the development of children's independent ability, prevents the child from communicating properly with others and leads to the lack of children's sense of teamwork.

\section{The Current Education of America Family Morality Education}

\section{Legislation Strengthens Morality}

Starting from the 1950s, education has experienced six waves of reform in the United States, which has laid the basic direction of education development in the United States today. In January 8, 2002, President Bush signed and approved landmark legislation that No Child Left Behind. This act has promoted the reform process of education in the form of law, and increased the implementation of education reform program with the force of law. The bill $<$ No Child Left Behind>, contains a few elements for family morality education: Love, the virtue of citizens, justice, respect and responsibility, trust, dedication[1]. For such morality and virtue education, most parents and teachers choose to support and cooperate with the development of children's good moral character and virtue character. In 2002 President Bush outlined the public education goals to the White House Character and Community Council. He advocates that education not only provides young people with knowledge and skills for employment, but also prepares them for life. Therefore, it is very important to cultivate morality and virtue of teenagers, especially in the family environment. 


\section{The Government Focuses on the Development of Moral Education}

In his 2009 speech, <The American Recovery and Reinvestment Act of 2009>, President Obama highlighted the importance of moral education. He was said: “America's greatest resource has never been our accumulated wealth, but what kind of education can we give our citizens." "The future belongs to countries that can provide the best education for their citizens.” [2] On December 10, 2015, Obama signed the <Every Student Succeeds Act>, which covers all aspects of education, basic education and higher education of children, and improves the education system of teenagers. Firstly, under the new law, state governments should adopt a unified and strict education evaluation standard. Secondly, improve education quality in backward areas. Establish a growth database system for each child to record the specific learning and growth of the child at different learning stages. In order to change the education plan or teaching mode for teenagers, they can guide children to develop in a better way.

\section{Promote Family Education Guidance Activities}

In American family morality education, firstly, parents pay attention to cultivating children's strong will and brave character; Secondly, they attach importance to building a harmonious, equal and democratic family environment; Thirdly, family ethics education emphasizes financial management education. The United States has always attached great importance to children's family education. Since the 1950s, states have actively carried out family education guidance activities. Early 1960s, Michigan has set up Perry Preschool Program Study to guide parents who are in poverty or the Chinese ethnic minorities in teaching their children. In 1965, congress passed the economic opportunity act, the beginning of the education movement. In 1965, the U.S. congress passed the economic opportunity act, which began the education campaign and required experts to guide family education, child development and moral development. In the early 1980s, several states with relatively developed education in United State took the lead in setting up the career of "family education instructor" to cultivate professional family education workers.

\section{Compare the Influence of Education on Family Morality between China and America}

\section{The Influence of Education on Family Morality in China}

Strong Family Consciousness and Patriotism. In Chinese families, traditional ethics and patriotism construct the main parts of education. Filial piety culture is the essence of Chinese traditional morality and the Chinese national virtue passed down across generations by Chinese families. Parents in daily life to the family and family member's selfless dedication, children are affected by their parents to the family members respect and filial piety, thus the family consciousness is very strong. In the Chinese family, the education of patriotism makes the children gradually establish the correct values of patriotism and collectivism from an early age. Therefore, children clearly know that the starting point of everything should be based on national and social collective interests as the center. Individual interests need to conform to national interests and social collective interests, at the same time, patriotism is deeply rooted in the thinking of teenagers. 


\section{The Unequal Status of Parents and Children Hinders the Cultivation of Family Morality Education}

In Chinese families, influenced by Confucianism and feudal patriarchal system for a long time, Chinese parents have an absolute say in the family. The concept of emperor with minister and father with son has been passed down across generations in Chinese families. He patriarchal education environment has formed the habit of unequal family education, which has exerted excessive restraint on the growth of teenagers. Parents are in a position of authority to manage their children, and communication with their children is often conducted in a command manner. Children do not have a strong sense of self-expression, and there is a lack of effective communication between parents and children. The lack of communication between parents and adolescents has gradually become a strong resistance to the smooth development of family moral education. Meanwhile, in the process of education, parents always tell their children to restrain themselves and follow the mainstream trend of social collective development. This excessive discipline greatly reduces children's enthusiasm for exploring new things and reduces their chances of social practice. Therefore, children are too dependent on their parents, which is not conducive to the development of their strong will and courageous character.

\section{The Influence of Family Morality Education of American}

Independent living ability is strong but the family consciousness of "respecting elders and filial piety" is weak. In American families, the cultivation of independent living ability is the main part of family morality education. American parents often spread adult thoughts and thinking patterns to their children too early. American children think earlier than their Chinese counterparts. In addition, after the age of 18, American students often leave their parents. Therefore, young people in the United States after the age of 18 have less time to live with their parents and have less responsibility to support their parents.

\section{Equal Status Promotes the Smooth Development of Family Ethics Education}

In the American families, the status of parents and children is equal. The communication between parents and children is mostly "discussion-style" dialogue. Children are good at expressing their wishes in the family. Therefore, the generation gap between parents and children is smaller when parents and children establish a friendly relationship of communication. Communication between parents and adolescents has gradually become a great advantage for the smooth development of family ethics education. American parents have always wanted their children to be active and individual. Since children are encouraged to express their ideas when they are young, this relaxed and open environment has greatly increased their enthusiasm for exploring new things. At the same time, the open family environment increases the opportunity of children's social practice, which is conducive to children's strong will and brave character.

\section{The Enlightenment of American Family Morality Education to our Country}

Strengthening the Construction of the Moral Education. Set up a professional family education guidance team, the experts of family education should improve the scientific discipline system of family moral education and clarify the construction direction of moral education. In the process of education adolescents, parents should strengthen the function of family moral education and enhance their own quality and ability in family moral education. 
In the process of social publicity, the concept of family education that conforms to the core socialist values should be advocated. For Chinese traditional culture, the public should inherit its essence and abandon the content that is not consistent with the modern trend. For areas with relatively backward economy and relatively closed ideology, especially for special groups such as left-behind children and children of migrant workers, the government should take precise measures to ensure that these areas and people have a harmonious family morality. To sum up, we should optimize and promote the moral education in family education, objective consider of "exam-oriented education". Only by clarifying the education content of family morality and adopting diversified education method of family morality can we have better moral education.

Avoid the Negative Factors of Traditional Family Morality Education. In China's feudal society, owning to the backward productivity, the conservative small-scale agricultural economy determines the social ideology and culture, so social thought is also relatively conservative and feudal. Restrict people's original active thought, mislead Chinese family moral education practice activity. This idea creates resistance on the path of talent training in China. Only when these negative factors are removed fundamentally will the development of Chinese family morality education cause become smoother.

First of all, avoid parent authoritarian ideology in family ethics education. The ideology of rule and hierarchy is the core ethics. In the family, the parents are the first to dominate all the housework, and the children must obey their parents' wishes and arrangements unconditionally. Parents' demands on teenagers have absolute authority in the family. This kind of education model based on parents' hierarchy neglects the normal development of children's body and mind, and kills their innovative thinking. Therefore, it is unfavorable for the construction of a harmonious family and education for talents with excellent academic quality.

Secondly, avoid parental hierarchy ideology in family ethics education. The feudal rulers intended to use the idea of hierarchy to make the masses obey the requirements of the government. Therefore, this kind of hierarchical feudalism also guides all aspects of family morality education. Under the influence of urbanization and modernization, although large families are rarely seen, parents' expectations are at the heart of education, and children's personal intentions are secondary to those of their parents. Some teenagers lose themselves in the process of growing up. The results of such cultivation are often narrow and selfish, and are unfavorable to the long-term development of the country and social stability.

Thirdly, avoid closed parenting in family ethics education. In traditional family morality education, parents often plan their children's life before they are born, and children can only follow their parents' plan after birth. Parents often impose severe punishment on children who do not conform to their parents' wishes. On the contrary, parents tend to overindulge teenagers who are obedient to their parents. In fact, for a child, he does not necessarily understand that the real reason for obeying his parents. But teenagers are simply submissive or fearful of parental authority, causes teenagers to lose the ability and judgment to think actively. In the end, children can only grow up under the protection of their parents, and they lack independence and innovation. When these children enter society, they lack the necessary independence, and parents are more likely to interfere in their children's work, marriage and offspring. This kind of conservative education is the adverse with modern multi element education parenting. 
Avoid Management Models of “4+2" Patter of Family Ethics Education. The management models of " $4+2$ " patter of family ethics education is that grandma and grandpa with the parents co-manage the child's model. This pattern is particularly striking in present China, because parents are busy at work, there is an obvious tendency for the seniors to directly manage education in their families. For example, transport teenagers to and from school, take care of the food and shelter of the youth, even participate in the process of learning knowledge. During this process, the ideas of grandparents naturally influence the life and study of future generations. Some of these ideas are correct, but others are outdated or spoiled. The government should introduce corresponding policies to ensure parents' time to accompany, education and take care of their children, which will greatly promote the growth of the next generation.

\section{Reference}

[1] Joel Spring, Zhang Chi, Zhang Binxian. American Education[M]. Anhui Education Press. 2010:4-5.

[2] Shi Jinghuan. Contemporary America education[M]. Beijing: social sciences academic press(CHINA). 2012:106. 